\title{
Law, Popular Culture and the Arts in the 21st Century
}

\author{
Peter Robson ${ }^{1} \cdot$ Sarah Marusek $^{2}$
}

Accepted: 28 August 2020 / Published online: 16 October 2020

(c) Springer Nature B.V. 2020

\section{Introduction}

Scholarly engagement with the interface between the formal justice system and popular culture has been relatively recent and has developed a tendency to focus on film. In the Bibliography of one of the early collections on Law and Film [1], the editors identified some 76 essays and books between 1986 and 2000. The first appeared in 1986 [2]. A broad expansive examination of popular culture was found in the 1992 meeting of American legal scholars [3]. This burgeoning movement examined film, television, light opera, women's studies and literature. Its approach has generally not been continued [4]. Rather we have, on the one hand, works in distinctive fields focusing on single phenomena like film [5] or television [6, 7]. Some areas have received scant attention [8]. In addition, there have been collections centring on a broad theme such as visual studies [9], cultural legal studies [10] or legal language [11]. The vast majority of the scholarship has been from a cultural studies viewpoint with elements of social scientific analysis also encountered. Here we seek to reflect what we see as the worthwhile goal of crossing between these boundaries and bringing together work from the distinct traditions of literary criticism, social science and semiotics.

Traditionally, semiotics has focused on visual representations of meaning [12]. Yet even the understanding of the visual has evolved from the static to the motile. Furthermore, the visual is no longer relegated to the framework of sighted, but instead the experience of seeing in media is synaesthetically expanded as a semiotic system [14] through the audible and the sensory [15]. The semiotics of law and popular culture embody a command of visual meaning that envisages the ordering of power through more than just the eyes, as the papers in this Special Issue show $[13,16,17]$.

Sarah Marusek

marusek@hawaii.edu

Peter Robson

peter.robson@strath.ac.uk

1 Glasgow, Scotland

2 Hilo, HI, USA 
This collection brings together work being done by scholars from around the world on the links between the justice system and its representation in a variety of quite distinct fields. They enable us to appreciate the existence of very different ways of focusing on how justice is meted out and its effects. Taken together, they provide a richer description of the phenomenon of law and how it can affect people's lives. The very real impact on individuals and groups which the operation of law has is emphasised through the various arts, whether they be in the visual media of paintings, films or television or through the written word of literature or song. We have organised these essays into these sub-categories but are keen to emphasise the links between these traditional art forms as well as newer phenomena like the internet. Hence there are essays on film, television, graphic art, literature, song and the internet. The essays provide a snapshot at the start of the third decade of the twenty-first century of the range of ways in which law's meaning is disseminated and how it has distinct nuances with different audiences.

\section{Film}

The most popular area for scholars' comments over the past 25 years has been that of film. In Freeman's 2005 overview of Law and Popular Culture [4] more than half of the volume was taken up with scholarship on film. Given the many attractions of the medium it is not surprising, that this emphasis of focus has continued [18, 19] and we have three pieces looking at film. Mikel Diez Sarasola in Hollywood, An American Factory of Soft Law and Social Order draws our attention to the significance of de Sousa Santos' Abyssal line between the Metropolitan and Colonial worlds as it is reflected in the film production of Hollywood. Through Hollywood films, the struggles for gender equality and diversity, difference, and socio-economic inequality are captured through the real critiques offered through science fiction and cinematic portrayal. This same Abyssal line is encountered in Laura Carballo Piñeiro's examination of films portraying one of the most significant social issues of this century, maritime migration, The Seventh Art and the Public Discourse on Maritime Migration. As crime scene to human smuggling, migrations at sea that result in drownings and insufficient responsibility assumed by implicated nations pits the Global North against the Global South in the quest for humanitarian movement of the world's peoples. The opportunity to enhance our understanding of film through psychoanalysis is encountered in Mark Featherstone's essay Primal Crime: Visions of the Law and Its Transgression on the films of Danish director Nicolas Winding Refn. Themes of crime, violence, law, and order characterize the dystopic structuring of family relationships in contemporary social systems. Finally, in Developments in Revenge, Justice and Rape in the Cinema, Peter Robson draws our attention to how film is publicised and mediated in the context of a wider recognition of dayto-day exploitation and abuse of women in Western culture. Justice and revenge emerge, alongside victimisation and vengeance, to deepen and complicate the misleading dichotomous fracture between right and wrong. 


\section{TV}

As has been pointed out elsewhere [20] film in popular culture scholarship has produced no less than twenty books, ten edited collections and eight special journal issues. Although we now have more work on television [21], this is still much rarer [22]. Stefan Machura and Olga Litvinova provide Reflection of Legal Culture in Television Comedy: Social Critique and Schadenfreude in the US Series "Frasier" where they suggest that by examining popular TV comedies we can gain an insight into popular legal culture. Comedy, or laughing at the familiar, reveals the sociolegal dimensions of law that are embraced as well as questioned through mockery and mundane acts of rule-breaking. The question of the conflict between what law offers and what fiction can provide as an account of how law operates is discussed in Truth Does Not Matter: Legal Storytelling in the Japanese Drama "Legal High 2 ” by Lung Lung $\mathrm{Hu}$. Narratives generated through storytelling create either legal fact and/or legal fantasy in ways that complicate the truth as another form of legal fiction.

\section{Graphic Art/Photography}

Nathalie Hauksson-Trench takes us through the artwork produced in relation to the notorious Dreyfus trial. In Visual Rhetoric of the Truth in the Dreyfus Affair: A Semiotic Approach she indicates the significance of these representations at early twentieth century French society. The meaning found in symbols and transmitted as messages speaks to the informational murkiness separating deceit from truth. The potential impact of trials to "outsiders" provides a valuable counterbalance to the unspoken assumptions which those of us who work in the system in some capacity operate with. Isobel Williams provides us with a contrast by expanding on this "outsider" perspective in her essay Drawn to Court: What Does the Unofficial Eye See? Drawing aspects of justice whether in the courtroom or on the street reveals insightful complexities into what law looks like. In Decoding the Crime Scene Photograph: Seeing and Narrating the Death of a Gangster, Anita Lam draws our attention to the way viewers identify with the law as a result of an image's visual structure, as well as through representational exchanges that blur the edges between fact and fiction. The role of audience is subject to the constructed (re)presentations of fact, fiction in legal narratives that are often out of focus.

\section{Song}

Two essays look at the neglected field of song. In Michael Freeman's overview of Law and Popular Culture in 2005 there were some 20 essays on film, 15 on literature but only two on song. This continues to be an area where scholarship is seldom encountered and there are no examples in the other collections with which we are familiar with their focus on the visual. David Ray Papke in Challenges to Criminal 
Labeling: Three Voices in American Popular Music, draws our attention to how the process of labelling operates in relation to crime in the United States and the role of popular music in providing some kind of challenge to this process. The cultural and social aspects of a thriving hegemony are tempered through critique, even as the level of semantic identities is heightened through the elevation of a humanized criminal committing a humanized crime. Philip Rodney in Prison and the Law in Modern American and British Popular Music, takes the theme of the songwriter outlaw and in particular incarceration. He suggests that, whilst there continue to be subversive elements in the songs of a range of artists over the years, these are to a large extent illusory and reflect an anti-establishment pose rather than any kind of political position. Their potential, though, as he points out in relation to gangs and rap artists in the modern-day world is not to be underestimated.

\section{Internet}

Soña Alexopoulos and Antonia Pavli respond to the question posed by the actions of hacker activists that they have become the Robin Hoods of the digital era in Beneath This Mask There is More Than Flesh, Beneath This Mask There is an Idea: Anonymous as the (Super)heroes of the Internet?. In ways that mimic the unidentifiable and unnamed life of the cyber realm, anonymity and activism become politicised identities in the faceless pursuit of justice and accountability.

\section{Literature}

There has been a tendency in the work on law and literature to focus on the power and significance of classic rather than popular fiction. This is reflected in the Freeman collection noted above. In this collection, a contemporary story is examined. Katerzyna Struzińska explores the merging of the actual and the fictional in the story of a convicted author and murderer, in The Murderer as Writer, Storyteller and Protagonist: The Case of Krystian Bala. The cultural reproduction of criminality is a terse and often befuddled mess of fact and perception that distorts, like in other areas of law and culture, what happened as well as what should happen.

Taken together these essays provide a range of different approaches from different disciplines and distinct jurisdictions to that most powerful yet fragile phenomenon, the formal justice system. Its power and strength are undoubted as we can see in the way in which such groups as migrants and protesters can be dealt with. Its limitations can also be appreciated when it fails to engage with the core value of supplying justice and maintaining the rule of law is supplanted by simplistic populism. Whether law can be seen as a vehicle of salvation or simply oppression that has always varied, part of the task of this volume to shine a light on some of the lesser known areas where law, justice and society intersect.

July 132020 . 


\section{References}

1. Machura, S., and P. Robson (eds.). 2001. Law and film. Oxford: Blackwell.

2. Chase, A. 1986. Towards a legal theory of popular culture. Wisconsin Law Review 527-569

3. Gunn, D. (ed.). 1993. The lawyer and popular culture. Littleton: Fred b Rothman.

4. Freeman, M. (ed.). 2005. Law and popular culture. Oxford: OUP. is an exception with its coverage noted below.

5. Sarat, A. 2009. Symposium on law and film, vol. 46. Studies in Law, Politics and Society Vol 46)

6. Jarvis, R., and P. Joseph (eds.). 1998. Prime time law: Fictional television as legal narrative. Durham: Carolina Academic Press.

7. Asimow, M. (ed.). 2009. Lawyers in your living room: Law on television. Chicago: ABA.

8. Robson, P. 2016. Law and the theatre (in Sharp and Leiboff (eds)).

9. Wagner, A., and R. Sherwin (eds.). 2014. Law, culture and visual studies. Dordrecht: Springer.

10. Sharp, C., and M. Leiboff (eds.). 2016. Cultural legal studies. Abingdon: Routledge.

11. Visconti, J. (ed.). 2018. Handbook of communication in the legal sphere. Berlin: De Gruyter Mouton.

12. Peirce, C. 1977. Semiotics and significs. Bloomington: Indiana Press.

13. Kevelson, R. (ed.). 1996. Spaces and significations. New York: Peter Lang.

14. Valverde, M. 2006. Law and order: Images, meanings, myths. New Brunswick: Rutgers University Press.

15. Nirta, C., D. Mandic, A. Pavoni, and A. Philippoupolos-Mihalopoulos. 2020. Law and the senses series. London: University of Westminster Press.

16. Neuwirth, R. 2018. Law in times of Oxymora: A synaesthesia of language, logic, and law. New York: Routledge.

17. Marusek, S. (ed.). 2017. Synesthetic legalities: Sensory dimensions of law and jurisprudence. New York: Routledge.

18. Wagner, A., and R. Sherwin. 2014. Law, culture and visual studies (Dordrecht, Springer) - there are 9 essays on film, 1 on a TV show and 1 covers both film and TV.

19. Strickland, R., T. Foster, and T. Banks (eds.). 2006. Screening justice: The cinema of law. Buffalo: WS Hein.

20. Robson, P., and J. Silbey (eds.). 2009. Law and justice on the small screen. Oxford: Hart.

21. Robson, P., and J. Schulz (eds.). 2016. A transnational study of law and justice on TV. Oxford: Hart.

22. Picart, C., M. Jacobsen, and C. Greek (eds.). 2016. Framing law and culture: An interdisciplinary anthology. Madison: Fairleigh Dickinson UP. 15 of the 17 essays are on film and 1 on TV - covering The Wire. One covers both film -18 pages and TV -6 pages

23. Robson, P., and J. Schulz. 2018. Ethnicity, gender and diversity: Law and justice on TV. Lanham: Lexington.

Publisher's Note Springer Nature remains neutral with regard to jurisdictional claims in published maps and institutional affiliations. 